\title{
ОСОБЛИВОСТІ ВИКОРИСТАННЯ ТА ЕФЕКТИВНІСТЬ ОСНОВНИХ КЛАСІВ ПРЕПАРАТІВ В ЛІКУВАННІ ІШЕМІЧНОЇ ХВОРОБИ СЕРЦЯ В ОСІБ СТАРШИХ ВІКОВИХ ГРУП
}

\author{
๑В. Ю. Жарінова, Г. П. Войнаровська \\ ДУ «Інститут геронтології імені Д. Ф. Чеботарьова НАМНУ», Київ
}

РЕЗЮмЕ. Значна смертність та низька якість життя хворих зумовили необхідність активного пошуку комбінацій препаратів, які 6 сприяли зменшенню ймовірності розвитку ускладнень і покращували прогноз перебігу кардіоваскулярних захворювань.

Мета - особливості використання та ефективність основних класів препаратів для лікування ішемічної хвороби серця (IXC) в осіб старших вікових груп.

Матеріал і методи. Було проаналізовано 220 історій хвороб пацієнтів віком 60-90 років з IXC, які перебували на стаціонарному та амбулаторному лікуванні у відділенні кардіології ду «ннститут геронтології ім. Д. Ф. Чеботарьова НАМНУ» в період 1997-2003 та 2015-2017 рр. Визначали частоту застосування окремих класів препаратів на цих етапах спостереження, частоту призначення різних схем лікування та їх вплив на тривалість життя осіб літнього віку, хворих на IXC. На другому етапі роботи було також проведено аналіз історій хвороб 488 пацієнтів, яких спостерігали в 1997-2017 рр. залежно від наявності інфаркту міокарда (IM) в анамнезі. За початкову точку спостереження було обрано дату першої госпіталізації в кардіологічне відділення. Всіх обстежених було вперше госпіталізовано в стаціонар і в подальшому їх спостерігали з основним діагнозом IXC: стабільна стенокардія напруги I-III ФК, СН 0-ІІ 6. Кінцевими точками спостереження вважали останню госпіталізацію на момент 2017 р. або настання смерті пацієнта. Як кінцеву точку було обрано смерть пацієнта, на основі якої вивчали показник тривалості життя (який визначали роком/віком смерті) або вік на момент 2017 року.

Результати. За даними спостереження відзначено, що в 1997-2003 рр. найчастіше призначуваними групами були: З-блокатори (57,2 \%), іАПФ (75,2 \%), АСК (73,7 \%), статини 60,1 \% і препарати нітрогліцеринового ряду (31,0 \%). Сартани призначали 10,67 \%, БКК - 26,2 \%. У 2015-2017 рр. препарати з групи інгібіторів ГМГ-КоАредуктази, за даними аналізу, стали призначатися в 81,1 \% випадків. Значно менше застосовували препарати нітрогліцеринового ряду - 17,9 \%. Зросла поширеність призначення антигіпертензивних препаратів: $\beta$-блокаторів (80,3 \%), блокаторів кальцієвих каналів (58,9 \%), інгібіторів рецепторів ангіотензину II (35,0 \%). Ацетилсаліцилову кислоту призначали у 83,7 \% випадків. Аналіз терапії хворих, які перенесли інфаркт міокарда (IM), свідчить про недостатнє призначення препаратів основних класів: ACK отримували 76,2 \%, статини 66,4 \%, 6ета-блокатори 73,7 \% ІАПФ 69,0 \%. У результаті застосування логістичної регресії було побудовано рівняння, згідно з яким може бути спрогнозована ймовірність розвитку інфаркту залежно від того, якими препаратами лікують хворого, крім того, за даними нашої моделі можна модифікувати терапію хворих, зменшувати ймовірність розвитку ІМ.

Висновки. Отримані результати свідчать, що найбільш ефективні комбінації лікування осіб з IXC, що впливають на тривалість життя, були у хворих, які приймали АСК, статини і бета-блокатори - $(81,4 \pm 3,16)$ року, АСК, статини і ІАПФ - $(80,1 \pm 1,71)$ року.

КЛючОВІ СЛОВА: ішемічна хвороба серця; пацієнти літнього віку; особливості лікування.

Вступ. За останні 30 років відзначається глобальне постаріння населення планети - це характерне демографічне явище сучасної епохи. За прогнозами Організації Об'єднаних Націй, у найближчі 40 років частка людей, старших 60 років, збільшиться майже в два рази і до 2050 року вона досягне 21,1 \% світового населення. Звідси випливає, що в даний момент кожна десята людина на Землі старша 60 років, а до 2050 року кожен п'ятий стане шістдесятирічним [1]. Швидкими темпами збільшується вікова група "найстаріших" (старших 80 років), щорічні темпи росту якої 4,2 \%. До 2050 року очікується, що в структурі населення людей, старших 80 років, буде майже $12 \%$ [2]. Як і в багатьох країнах світу, в Україні збільшилася кількість людей похилого і старечого віку. У 1950 р. осіб віком понад 60 років значилося 10,9 \%, в 2000 р. - 20,5 \% і прогнозується до 2050 збільшення до 38,1 \%. Надалі високим залишається рівень захворюваності та смертності в цій віковій групі внаслідок кардіоваскулярних захворювань, зокрема ішемічної хвороби серця (IXC). За статистичними даними різних країн, клінічні форми IXC реєструються у 15-20\% дорослого населення [3]. У нашій країні саме вона на 68,9 \% визначає рівень смертності від серцево-судинних захворювань (СС3) усього населення $[4,5]$. Haceлення неухильно старіє, й актуальність лікування і дослідження хворих геріатричної групи зростає [6]. Згідно з рекомендаціями Європейської спільноти кардіологів (2013) головною стратегією лікування хворих на стабільну IXC $\epsilon$ профілактика розвитку інфаркту міокарда (IM) і раптової серцевої смерті (РCC), тобто поліпшення прогнозу. Крім того, у структурі широкомасштабних проспективних досліджень частка хворих похилого віку $\epsilon$ не- 
Огляди літератури, оригінальні дослідження, погляд на проблему, випадок з практики, короткі повідомлення значною, майже всі дослідження проводяться із залученням осіб середнього віку. Між тим, найбільша розповсюдженість ССЗ і факторів кардіоваскулярного ризику (ФКР), що ускладнюють їх перебіг, спостерігається у осіб літнього віку $[7,8]$. Саме тому вкрай важливим $є$ проведення досліджень, покликаних вивчити призначення, прихильність до лікування та оцінку ефективності впливу на тривалість життя основних класів препаратів для лікування ССЗ у пацієнтів літнього віку з IXC.

Мета - визначити особливості використання та ефективність основних класів препаратів для лікування IXC в осіб старших вікових груп.

Матеріал і методи дослідження. На першому етапі нашої роботи було проаналізовано 220 історій хворо6 пацієнтів віком 60-90 років з IXC, які перебували на стаціонарному та амбулаторному лікуванні у відділенні кардіології ду «Інститут геронтології ім. Д. Ф. Чеботарьова НАМНУ» в період 1997-2003 рр. та 2015-2017 рр. У дослідження було включено як чоловіків - 107, так і жінок - 113. Визначали частоту застосування окремих класів препаратів на цих етапах спостереження, частоту призначення різних схем лікування та їх вплив на тривалість життя осіб літнього віку, хворих на IXC. На другому етапі нашої роботи було також проведено аналіз історій хвороб 488 пацієнтів, яких спостерігали у 1997-2017 рр. залежно від наявності інфаркту міокарда (IM) в анамнезі. За початкову точку спостереження було обрано дату першої госпіталізації в кардіологічне відділення. Всі обстежені були вперше госпіталізовані в стаціонар і в подальшому спостерігалися з основним діагнозом IXC: стабільна стенокардія напруги І-ІІІ ФК, СН 0-ІІ 6. Кінцевими точками спостереження вважали останню госпіталізацію на момент 2017 р. або настання смерті пацієнта. Як кінцеву точку було обрано смерть пацієнта, на основі якої вивчали показник тривалості життя (який визначали роком/ віком смерті) або вік на момент 2017 року. Діагноз основного захворювання встановлювали на підставі загальноклінічних обстежень і спеціальних інструментальних і лабораторних методів відповідно до поточних рекомендацій з діагностики IXC на етапі обстеження хворих. 3 аналізу виключали хворих із вадами серцевих клапанів, запальними ураженнями серця, клінічно значущою неврологічною патологією: гострими порушеннями мозкового кровообігу, дисциркуляторною енцефалопатією III ст. деменцією різного генезу, периферичною нейропатією, ендокринологічною патологією за винятком ЦД ІІ типу, патологією кровотворної системи, а також онкологічними захворюваннями, шлуночковими порушеннями ритму, які могли 6 вплинути на виникнення кінцевої точки.

Методи статистичної обробки отриманих даних. Статистичну обробку даних проводили методами варіаційної статистики за допомогою пакета статистичних програм SPSS v.22, STATISTICA 7.0, MedCalc Statical Software v.11.5.0.0. Для показників, що мали нормальний розподіл, застосовували параметричні методи статистичної оцінки. Розраховували середні арифметичні величини показників (М), їх похибки (m) в різних групах обстежених, а також середні величини зрушень показників (та їх похибки). Для оцінки достовірності відмінностей середніх величин використовували критерій біжності при досягненні рівня значущості $p<0,05$ для незалежних і залежних сукупностей. 3 метою оцінки взаємозв'язків застосовували кореляційний аналіз. Для порівняння частоти виникнення якісних показників застосовували критерій $\chi^{2}$ Пірсона для таблиць сполученості з поправкою Йєйтса. Для оцінки прогностичного значення показника застосовували ROC-аналіз, прогностичну силу моделі визначала площа під кривою (AUC).

Результати й обговорення. 3 метою визначення тенденцій у лікуванні осіб літнього віку, хворих на IXC, в період розробки та широкого впровадження в медичну практику препаратів, що $\epsilon$ основою сучасних рекомендацій із профілактики і лікування ССЗ, було проаналізовано терапевтичні схеми та визначено частоту застосування окремих класів препаратів на етапах 19972003 та 2015-2017 років.

Для реалізації даної мети було проаналізовано 103 історії хвороб пацієнтів, що були госпіталізовані в 1997-2003 рр., і 117 історій хвороб 20152017 рр. Клінічна характеристика хворих представлена в таблиці 1.

Як свідчать наведені дані, за тяжкістю перебігу захворювання, наявністю коморбідних станів та факторів КВР групи статистично не відрізнялися. Група пацієнтів, які були включені в дослідження у 2015-2017 рр., відрізнялась нижчим рівнем загального холестерину та ЛПНЩ, вірогідно меншою абсолютною та відсотковою кількістю IM та ГПМК в анамнезі. Отримані дані свідчать про поступове вдосконалення терапії осіб літнього віку з IXC і більш широке впровадження цих рекомендацій у даній категорії хворих.

При порівнянні схем лікування на двох етапах спостереження визначено, що 20 років тому (в 1997-2003 рр.) найчастіше для лікування IXC в осіб старшого віку застосовувались іАПФ (75,2%), ß-блокатори (57,2 \%), ацетилсаліцилова кислота (АСК) 73,7 \%, статини - 60,1\% та препарати нітрогліцеринового ряду (31,0 \%). Значно рідше в листах призначення зустрічались блокатори кальцієвих каналів (БКК) - 26,2 \%, сартани - 10,67 \%. У 
Огляди літератури, оригінальні дослідження, погляд на проблему, випадок з практики, короткі повідомлення Таблиця 1. Клінічна характеристика включених у дослідження хворих (\%)

\begin{tabular}{|c|c|c|c|c|}
\hline Показники & $\begin{array}{c}1997-2003 \text { pp. } \\
(n=103)\end{array}$ & $\begin{array}{l}2015-2017 \mathrm{pp} . \\
(\mathrm{n}=117)\end{array}$ & Критерій & $P$ \\
\hline IXC & $103(100 \%)$ & $117(100 \%)$ & $\chi^{2}=0,39$ & 0,534 \\
\hline Середній вік, роки & $69,9 \pm 19,0$ & $68,2 \pm 7,07$ & $t=0,08$ & $p>0,05$ \\
\hline Чоловіки & $53(51,4 \%)$ & $54(46,1 \%)$ & $\chi^{2}=0,42$ & 0,515 \\
\hline Жінки & $50(48,5 \%)$ & $63(53,8 \%)$ & $\chi^{2}=0,42$ & 0,515 \\
\hline $\begin{array}{l}\text { Стенокардія напруги } \\
\text { І ФК }\end{array}$ & $20(19,4 \%)$ & $25(21,3 \%)$ & $\chi^{2}=0,04$ & 0,849 \\
\hline $\begin{array}{l}\text { Стенокардія напруги } \\
\text { ІІ ФК }\end{array}$ & $66(64,0 \%)$ & $87(74,3 \%)$ & $\chi^{2}=2,27$ & 0,131 \\
\hline $\begin{array}{l}\text { Стенокардія напруги } \\
\text { ІІІ ФК }\end{array}$ & $17(16,5 \%)$ & $5(4,27 \%)^{*}$ & $\chi^{2}=7,80$ & 0,005 \\
\hline AT>140/90 мм рт. ст. & $69(66,9 \%)$ & $85(72,6 \%)$ & $\chi^{2}=0,59$ & 0,443 \\
\hline САТ, мм рт. СТ. & $150,8 \pm 17,6$ & $146,5 \pm 7,07$ & $\chi^{2}=0,23$ & $p>0,05$ \\
\hline ДАТ, мм рт. ст. & $87,0 \pm 17,6$ & $85,2 \pm 10,8$ & $\chi^{2}=0,09$ & $p>0,05$ \\
\hline ГХ 1 ст. & $6(5,8 \%)$ & $4(3,41 \%)$ & $\chi^{2}=0,28$ & 0,595 \\
\hline ГХ 2 ст. & $35(33,9 \%)$ & $74(63,2 \%) *$ & $\chi^{2}=17,62$ & 0,000 \\
\hline ГХ 3 ст. & $49(47,5 \%)$ & *33 (28,2 \%) & $\chi^{2}=7,98$ & 0,004 \\
\hline ЦД \% 2 тип & $21(20,3 \%)$ & $25(21,3 \%)$ & $\chi^{2}=0,94$ & 0,332 \\
\hline Куріння \% & $34(29,0 \%)$ & $32(27,3 \%)$ & $\chi^{2}=0,59$ & 0,443 \\
\hline ЗХС>4,5 ммоль/л & $72(69,9 \%)$ & $58(49,5 \%) *$ & $\chi^{2}=8,54$ & 0,003 \\
\hline лПНШ>2,5 ммоль/л & $76(73,7 \%)$ & $62(52,9) *$ & $\chi^{2}=9,26$ & 0,002 \\
\hline ЛПВШ<1,4 моль/л & $39(37,8 \%)$ & $60(51,2 \%)$ & $\chi^{2}=3,46$ & 0,062 \\
\hline IM в анамнезі & $49(47,5 \%)$ & $33(27,3 \%) *$ & $\chi^{2}=7,98$ & 0,004 \\
\hline $\mathrm{CH} 1 \mathrm{cT}$. & $62(60,1 \%)$ & $54(46,15 \%)^{*}$ & $\chi^{2}=3,79$ & 0,051 \\
\hline $\mathrm{CH} 2 \mathrm{~A} \mathrm{CT}$. & $23(22,3 \%)$ & $11(9,4 \%)^{*}$ & $\chi^{2}=6,05$ & 0,013 \\
\hline $\mathrm{CH} 2 \mathrm{~B} \mathrm{CT.}$ & $2(1,94 \%)$ & $1(0,85 \%)$ & $\chi^{2}=0,01$ & 0,911 \\
\hline ФП пароксизмальна форма & $5(4,8 \%)$ & $15(12,8 \%)$ & $\chi^{2}=3,30$ & 0,069 \\
\hline ФП постійна форма & $3(2,9 \%)$ & $10(8,5 \%)$ & $\chi^{2}=2,20$ & 0,138 \\
\hline ГПМК в анамнезі & $10(9,7 \%)$ & $3(2,5 \%)^{*}$ & $\chi^{2}=3,83$ & 0,050 \\
\hline
\end{tabular}

Примітка. * - розбіжності достовірні порівняно з першою групою $(p<0,05)$;

66,0 \% випадків призначали препарати метаболічної дії $(66,0 \%)$ серед яких у той період переважали: рибоксин - 29,1\%, тіотріазолін - 36,9\%.

у 2015-2017 роках значно збільшилась частота застосування інгібіторів ГМГ КоА-редуктази (статинів) - до 81,1 \% випадків, $\beta$-блокаторів $80,3 \%$, БКК - 58,9\%. Призначення інгібіторів АПФ $(66,6 \%)$ знизились за рахунок збільшення призначень інгібіторів рецепторів ангіотензину II (35,0\%). ACK призначалась у 83,7 \% випадків. Значно менше стали застосовувати препарати нітрогліцеринового ряду - $17,9 \%$. Метаболічну терапію призначали 83,7 \% хворим з IXC похилого віку. В більшості випадків призначали: триметазидин (53,3 \%), тіотріазолін (23,3\%), мельдоній (18,4 \%). Значний відсоток призначення хворим старших вікових груп препаратів метаболічної дії зумовлений віковими особливостями перебігу у них захворювань та змінами фармакодинаміки і фармакокінетики ліків на фоні структурних, метаболічних та функціональних зрушень старіючого організму (табл. 2).

Отримані дані свідчать про поступове вдосконалення терапії осіб літнього віку з IXC і більш широким впровадженням цих рекомендацій у даній категорії хворих.

Про доцільність лікування осіб літнього віку за стандартами лікування IXC свідчать результати визначення залежності тривалості життя хворих від прихильності до лікування та виду отриманої терапії (табл. 3), отримані завдяки проспективному аналізу історій хвороб 117 пацієнтів похилого та старечого віку, хворих на IXC, яким при виписуванні із стаціонару на тривалий час були призначені препарати базисної терапії та надана інформація відносно дотримання рекомендацій щодо корекції факторів ризику, в період між госпіталізаціями. У результаті опитування з'ясовано, що 87 (74,3%) хворих похилого віку виконують рекомендації лікаря і прийма- 
Огляди літератури, оригінальні дослідження, погляд на проблему, випадок з практики, короткі повідомлення Таблиця 2. Частота приймання різних класів препаратів у групах дослідження (\%)

\begin{tabular}{|c|c|c|c|c|}
\hline Препарати & $\begin{array}{c}1997-2003 \text { pp. } \\
\quad(n=103)\end{array}$ & $\begin{array}{c}2015-2017 \text { pp. } \\
\quad(n=117)\end{array}$ & Критерій & $P$ \\
\hline Бета-блокатори & $59(57,2 \%)$ & $94(80,3 \%) *$ & $\chi^{2}=12,69$ & 0,000 \\
\hline ІАПФ & $78(75,2 \%)$ & $78(66,6) \%$ & $\chi^{2}=1,76$ & 0,184 \\
\hline ACK & $76(73,7) \%$ & $98(83,7 \%)$ & $\chi^{2}=2,72$ & 0,099 \\
\hline Сартани & $11(10,67 \%)$ & $41(35,0 \%) *$ & $\chi^{2}=16,69$ & 0,000 \\
\hline Статини & $62(60,1 \%)$ & $95(81,1 \%) *$ & $\chi^{2}=10,82$ & 0,001 \\
\hline БКК & $27(26,2 \%)$ & $69(58,9 \%) *$ & $\chi^{2}=22,59$ & 0,000 \\
\hline Нітрати & $32(31,0 \%)$ & $21(17,9 \%) *$ & $\chi^{2}=4,46$ & 0,034 \\
\hline Діуретики & $34(33,0 \%)$ & $61(51,2 \%) *$ & $\chi^{2}=7,41$ & 0,006 \\
\hline Антиаритміки & $5(4,8 \%)$ & $15(12,8 \%)$ & $\chi^{2}=3,30$ & 0,069 \\
\hline Антикоагулянти & $5(4,8 \%)$ & $16(13,6 \%) *$ & $\chi^{2}=3,97$ & 0,046 \\
\hline Метаболічна терапія & $68(66,0 \%)$ & $98(83,7 \%) *$ & $\chi^{2}=8,38$ & 0,003 \\
\hline
\end{tabular}

Примітка. * - розбіжності достовірні порівняно з першою групою $(p<0,05)$.

Таблиця 3. Тривалість життя осіб літнього віку залежно від застосування окремих класів препаратів для лікування IXC

\begin{tabular}{|l|c|c|c|}
\hline \multicolumn{1}{|c|}{ Група препаратів } & Не приймали & Приймали & $\mathrm{p}$ \\
\hline АСК & $74,7 \pm 1,6$ & $78,9 \pm 1,3^{*}$ & $\mathrm{p}<0,05$ \\
\hline Статини & $74,6 \pm 1,1$ & $77,8 \pm 1,1^{*}$ & $\mathrm{p}<0,05$ \\
\hline В-блокатор & $72,69 \pm 2,17$ & $79,06 \pm 2,26^{*}$ & $\mathrm{p}<0,05$ \\
\hline ІАПФ & $72,69 \pm 7,17$ & $77,06 \pm 7,26^{*}$ & $\mathrm{p}>0,05$ \\
\hline Блокатор Са-каналів & $75,64 \pm 6,02$ & $75,05 \pm 6,09$ & \\
\hline
\end{tabular}

Примітка. * - розбіжності достовірні порівняно з пацієнтами, які не приймали препарат ( $<<0,05)$.

ють основні групи препаратів для лікування IXC, а $30(25,6 \%)$ пацієнтів не приймали препарати регулярно. Ці дані свідчать про високий показник прихильності до лікування, порівняно із популяцією середніх вікових груп за даними літератури [9].

Зважаючи на те, що пацієнти отримували комбіновану терапію (рис. 1) було проаналізовано кількість отримуваних препаратів (рис. 2).

При аналізі виявлено, що більшість пацієнтів отримувала від 3 до 5 препаратів. Також ми проаналізували тривалість життя хворих, що отримували найбільш типові комбінації препаратів.

Згідно з отриманими даними, найбільша тривалість життя була у хворих, які лікувались АСК, статинами та бета блокаторами - $(81,4 \pm 3,16)$ року, ACK, статинами та ІАПФ - $(80,1 \pm 1,71)$ року, АСК, статинами та БКК - $(78,7 \pm 4,24)$ року. У пацієнтів, які приймали ацетилсаліцилову кислоту та інгібітори АПФ, але не отримували в схемі лікування статини, трива- лість життя склала $(78,5 \pm 3,83)$ року, при призначенні ацетилсаліцилової кислоти і бета-блокаторів - $(78,6 \pm 4,82)$ року, ацетилсаліцилової кислоти та блокаторів Са-каналів - $(76,3 \pm 6,07)$ року. Отже, найбільша тривалість життя була у хворих, які отримували ацетилсаліцилову кислоту, гіполіпідемічну терапію та бета-блокатори - $(81,4 \pm 3,16)$ року (рис. 1$)$.

Отримані результати мають логічне пояснення, оскільки такі, як бета-блокатори, відносять до «препаратів номер один» для зменшення вираженості ангінозного болю при IXC у пацієнтів старшого віку та при поліморбідності. Крім того, в наведених нами дослідженнях доведено важливість зниження підвищеного внутрішньосудинного тромбоутворення в патогенезі ішемічного синдрому у Хворих на IXC літнього віку і важливість призначення антитромботичних засобів для покращення тривалості життя хворих [10]. Таким чином, отримані дані свідчать про необхідність приймання 
Огляди літератури, оригінальні дослідження, погляд на проблему, випадок з практики, короткі повідомлення

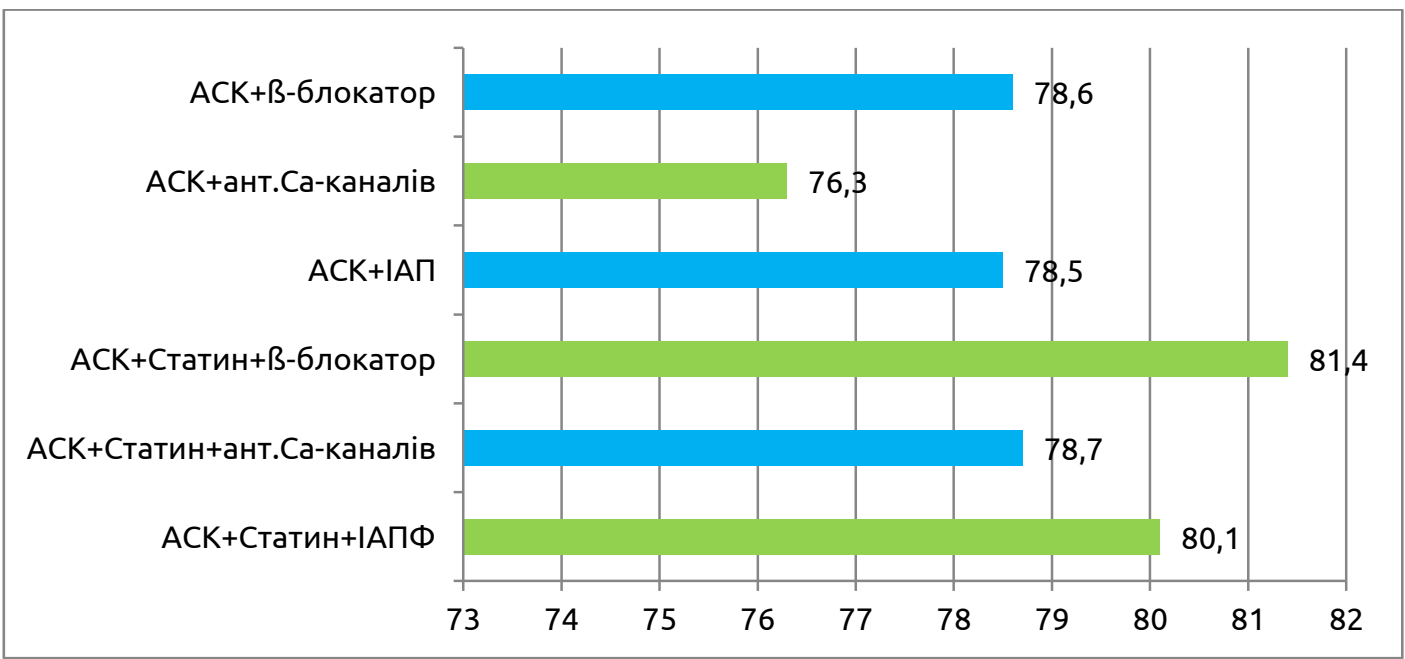

Рис. 1. Тривалість життя хворих, що отримували різні комбінації препаратів для лікування IXC.

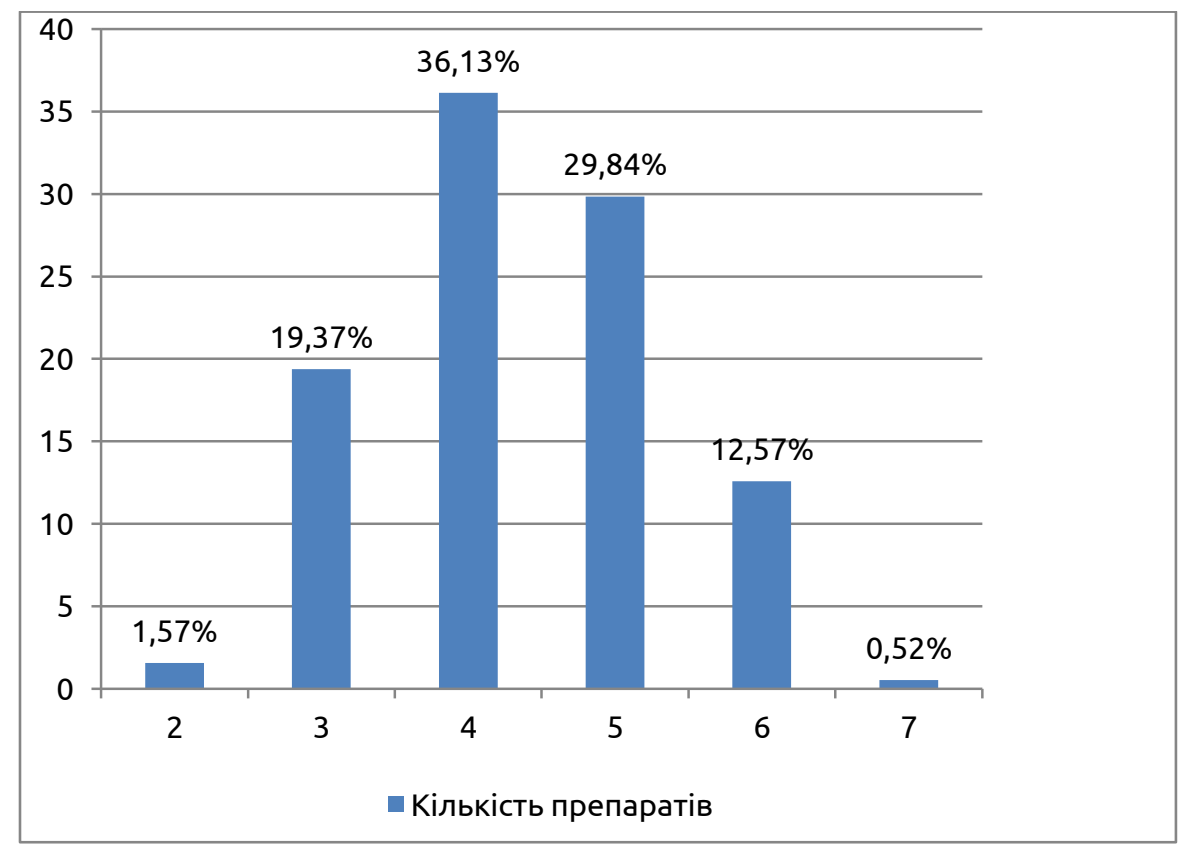

Рис. 2. Кількість отримуваних препаратів (\%).

призначеного лікування та регулярного взаємозв'язку між пацієнтом і лікарем.

Зважаючи на те, що IM є однією з основних причин смерті хворих на IXC і найбільш прогностично несприятливим ускладненням перебігу захворювання, у нашому дослідженні було також проведено аналіз історій хвороб залежно від наявності ІМ в анамнезі: 1-ша група (n=194) - пацієнти з IM в анамнезі, 2-га група (n=294) - пацієнти без ІМ в анамнезі.

Частота застосування окремих класів препаратів та спрогнозована ймовірність розвитку IM залежно від того, якими препаратами лікувався хворий, наведені в таблиці 4.
Отримані дані свідчать про вкрай недостатнє призначення основних класів препаратів в осіб першої групи, порівняно з пацієнтами другої групи. Можна припустити, що недостатнє призначення препаратів було пов' язане з малою розповсюдженістю їх на фармацевтичному ринку та відсутністю достатньої інформованості лікарів про необхідність жорсткої корекції ФКР. Так, відзначено, що пацієнти отримували значно менше АCK $(76,2$ \% і $83,3, \%$, р<0,05), статинів $(66,4 \%$ і $90,8 \%, p<0,05)$, бета-блокаторів - (73,7 \% і 84,3\%, р<0,05), ІАПФ (69,0 \% і 77,5 \% р<0,05). Водночас, згідно з отриманими даними, для осіб похилого віку відношення шансів ризику розвитку IM при прийманні АСК ста- 
Огляди літератури, оригінальні дослідження, погляд на проблему, випадок з практики, короткі повідомлення Таблиця 4. Частота приймання різних класів препаратів у групі дослідження (\%)

\begin{tabular}{|l|c|c|c|c|}
\hline \multicolumn{1}{|c|}{ Препарати } & $\begin{array}{c}1 \text { група пацієнти } \\
\text { з IM } \\
(\mathrm{N}=194)\end{array}$ & $\begin{array}{c}2 \text { група } \\
\text { пацієнти без IM } \\
(\mathrm{N}=294)\end{array}$ & Критерій & P \\
\hline Бета-блокатори & $143(73,7 \%)$ & $248(84,3 \%)^{*}$ & $\chi^{2}=7,66$ & 0,005 \\
\hline IАПФ & $134(69,0 \%)$ & $228(77,5 \%)^{*}$ & $\chi^{2}=3,96$ & 0,046 \\
\hline АСК & $146(76,2 \%)$ & $245(83,3 \%)^{*}$ & $\chi^{2}=4,29$ & 0,038 \\
\hline Сартани & $40(20,6 \%)$ & $66(22,4 \%)$ & $\chi^{2}=0,14$ & 0,713 \\
\hline Статини & $129(66,4 \%)$ & $267(90,8) \% *$ & $\chi^{2}=43,62$ & 0,119 \\
\hline БКК & $81(41,7 \%)$ & $101(34,3 \%)$ & $\chi^{2}=2,43$ & 0,000 \\
\hline Нітрати & $74(38,1 \%)$ & $54(18,3 \%)$ & $\chi^{2}=22,61$ & 0,877 \\
\hline Діуретики & $86(44,3 \%)$ & $127(43,1 \%)$ & $\chi^{2}=0,02$ & 0,998 \\
\hline Антиаритміки & $16(8,2 \%)$ & $23(7,8 \%)$ & $\chi^{2}=0,00$ & 0,020 \\
\hline Антикоагулянти & $28(14,4 \%)$ & $22(7,4 \%)^{*}$ & $\chi^{2}=5,41$ & 0,165 \\
\hline Метаболічна терапія & $157(80,9 \%)$ & $253(86,0 \%)$ & $\chi^{2}=1,92$ & \\
\hline
\end{tabular}

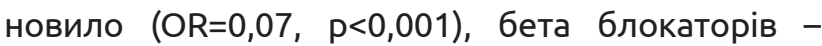
$(O R=0,14, p<0,001)$, статинів (OR=0,09, $p<0,001)$, IAПФ $(\mathrm{OR}=0,09, \mathrm{p}<0,001)$, що свідчить про надзвичайну важливість застосування зазначених класів препаратів у хворих на IXC похилого і старечого віку.

Отримані нами дані мають велике практичне значення з огляду на те, що для участі в дослідженнях, які стали основою для формування сучасних рекомендацій з лікування IXC, залуча- ли переважно осіб середнього віку. Зважаючи на наявність особливостей впливу основних класів препаратів на прогноз перебігу IXC в осіб літнього віку було побудовано рівняння, згідно з яким може бути спрогнозована ймовірність розвитку інфаркту [11] залежно від того, якими препаратами лікують хворого та можна модифікувати терапію хворих, зменшувати ймовірність розвиткy IM.

$\mathrm{Y}=1,70 \times$ Антикоагулянти + 0,28 $\times$ Антиаритміки - 3,48 $\times$ Аспірин - 2,57 $\times$ Бета_блокатор - 0,85 $\times$ БКК + 2,5 $\times$ ГХ + 1,22 × Діабет + 4,29 × Діуретик - 2,52 × ІАПФ + 0,44 × Мета6. тер. + 3,04 × Нітрогліцерин + 0,52 × Сартани + 3,13 × Серцева_недост. - 3,09 × Статини - 1,45 × Стать - 3,76 × ФП-3,74,

де $\mathrm{Y}$ - теоретичний коефіцієнт розвитку IM. Стать (1 - чоловіки, 2 - жінки) препарати (1 - вживали, 0 - не вживали), ГХ, ЦД, СН, ФП (1- $\epsilon, 0-$ немає). Застосовуючи формулу логіт-перетворення, отримаємо значення ймовірності розвитку ІМ в діапазоні від 0 (низька ймовірність) до 1 (висока ймовірність). Точність моделі - 97 \%. Належність до групи 0 - "немає інфаркту" - визначається моделлю 3 точністю 98,3 \%, а належність до групи 1 - "€ інфаркт" - з точністю 91,5 \%, площа під кривою AUC = 0,993 (0,981 до 0,999), xi = 384,7 квадрат, $p<0,001$. За допомогою даного рівняння були обчислені теоретичні значення коефіцієнта ймовірності розвитку IM для кожного пацієнта. Таким чином, було створено формулу, яка на підставі простої оцінки комбінацій використаних препаратів у пацієнта дозволяє об' єктивно висловлюватися про прогнозування розвитку ІМ в пацієнтів залежно від комбінації препаратів, якими лікується (лікувався) хворий, а також за даними нашої моделі можна модифікувати терапію хворих, зменшувати ймовірність розвитку IM.

Висновки: 1. Аналіз терапії за класами препаратів згідно з даними, отриманими в 1997-2003 рр., показав, що найчастіше призначуваними групами були: іАПФ (75,2 \%), ß-блокатори (57,2 \%), АСК $(73,7 \%)$, статини $(60,1 \%)$ та препарати нітрогліцеринового ряду (31,0 \%). Сартани призначали у $10,67 \%$, БКК - у $26,2 \%$.

2. У 2015-2017 рр. препарати з групи інгібіторів ГМГ КоА-редуктази, за даними аналізу, стали призначати до 81,1 \% випадків. Майже не застосовували препарати нітрогліцеринового ряду - 17,9 \%. Зросла поширеність призначення антигіпертен-

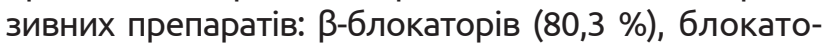
рів кальцієвих каналів (58,9\%). Призначення інгібіторів АПФ (66,6 \%) незначно знизили за рахунок збільшення призначень інгібіторів рецепторів ангіотензину II (35,0%). Ацетилсаліцилову кислоту призначали у 83,7 \% випадків.

3. Найбільш ефективними комбінаціями для лікування осіб з IXC, що впливають на тривалість життя, є: комбінації АСК, статини та бета-блокатори - $(81,4 \pm 3,16)$ року, АСК, статини та ІАПФ $(80,1 \pm 1,71)$ року, АСК, статини та БКК $(78,7 \pm$ $4,24)$ року. У пацієнтів, які приймали ацетилсаліцилову кислоту та інгібітори АПФ, але не отримували в схемі лікування статини, тривалість життя 
Огляди літератури, оригінальні дослідження, поглядн на склала $(78,5 \pm 3,83)$ року, при призначенні ацетилсаліцилової кислоти і бета-блокаторів - $(78,6 \pm$ 4,82) року, ацетилсаліцилової кислоти та блокаторів Са-каналів - $(76,3 \pm 6,07)$ року.

4. Аналіз терапії хворих, які перенесли IM, свідчить про недостатнє призначення препаратів основних класів: АСК отримували 76,2 \%, статини 66,4 \%, бета-блокатори - 73,7 \%, ІАПФ - 69,0 \%. Пацієнти без IM в анамнезі отримували АСК в 83,3 \%

\section{ЛІТЕРАТУРА}

1. Державна служба статистики України. Демографічна ситуація в Україні у 2014 році: експрес-випуск [Електронний ресурс]. - К. : Держ. служба статистики України, 2015. - Режим доступу до документа: http:// www.ukrstat.gov.ua.

2. Щорічна доповідь про стан здоров' я населення, санітарно-епідемічну ситуацію та результати діяльності систем охорони здоров'я України. 2016 рік / за ред. П. С. Мельника, Г. О. Слабкого, О. М. Дзюби [та ін.]. - К. : ДУ «УІСД МОЗ України», 2017. - 516 с.

3. Проблеми здоров'я і тривалості життя в сучасних умовах : посібник / за ред. В. М. Коваленка, В. М. Корнацького. - К., 2017. - 209 с.

4. Ішемічна хвороба серця у людей похилого віку: діагностика, лікування, спостереження : для сімейних лікарів, кардіологів, терапевтів / О.І.Дядик, А. Е. Багрій, І. Н. Циба [та ін.]. - Донецьк : Кусум Фарм, 2013. - 28.

5. Prevention of cardiovascular disease guided by total risk estimations - challenges and opportunities for practical implementation: highlights of a cardiovascular clinical trialists (CVCT) Workshop of the ESC Working Group on CardioVascular Pharmacology and Drug Therapy/F.Zannad, J. Dallongeville, R. J. Macfadyen [et al.] // Eur. J. Prev. Cardiol. - 2012. - Vol. 19 (6). - P. 1454-1464.

6. World Health Statistics 2017: Monitoring Health

\section{REFERENCES}

1. Derzhavna sluzhba statystyky Ukrainy (2015). Demohrafichna sytuatsiia v Ukraini u 2014 rotsi: ekspres-vypusk [Demographic situation in Ukraine in 2014: express issue]. Kyiv: Derzh. sluzhba statystyky Ukrainy. Retrieved from: http://www.ukrstat.gov.ua. [in Ukrainian].

2. Melnyk, P.S., Slabkyi, H.O., Dziuba, O.M., Chepelevska, L.A., \& Kudrenko, M.V. (2017). Shchorichna dopovid pro stan zdorovia naselennia, sanitarno-epidemichnu sytuatsiiu ta rezultaty diialnosti system okhorony zdorovia Ukrainy. 2016 rik [Annual report on the state of health of the population, the sanitary-epidemic situation and the results of the activity of the health care systems of Ukraine. 2016]. Kyiv: DU "UISD MOZ Ukrainy" [in Ukrainian].

3. Kovalenko, V.M., \& Kornatskyi, V.M. (2017). Problemy zdorovia i tryvalosti zhyttia v suchasnykh umovakh: posibnyk [Problems of health and life expectancy in today's context: manual]. Kyiv [in Ukrainian].

4. Diadyk, O.I., Bahrii, A.E., Tsyba, I.N., Shchukina, O.V., Khomenko, M.V., Hnilytska, V.B., ..., \& Bahrii, EA. (2013). Ishemichna khvoroba sertsia u liudei pokhyloho viku: diah- for the Sustainable Development Goals (SDGs). - Geneva : World Health Organization, 2017. - 112 p.

7. Фармакотерапия в гериатрической практике : рук. для врачей / Р. К. Кантемирова, В. Г. Чернобай, А. Л. Арьев, С. Д. Дзахова. - СПб. : СпецЛит, 2010. - 158 с.

8. Особенности фармакотерапии у пожилых пациентов. Введение в проблему / Е. А. Ушкалова, О. Н. Ткачева, Н. К. Рунихина [и др.] // Рацион. фармакотерапия в кардиологии. - 2016. - Т. 12, № 1. - С. 94-100.

9. Contemporary management of octogenarians hospitalized for heart failure in Europe: Euro Heart Failure Survey II / M. Komajda, O. Hanon, M. Hochadel [et al.] // Eur. Heart J. - 2009. - Vol. 30 (4). - P. 478-486. DOI: 10.1093/eurheartj/ehn539.

10. Пат 96488 Україна. МПК А61 К 31/175, А 61 P 9/00. Спосіб лікування порушень гемоваскулярного гемостазу у хворих на ішемічну хворобу серця / В. Ю. Жарінова, Л. А. Бодрецька, О. В. Коркушко, К. М. Ігрунова, Ж. С. Бутинець, Л. М. Кохановська ; ДУ «Інститут геронтології ім. Д. Ф. Чеботарьова НАМН України». - № 201408776 ; заявл. 04.08.2014; опубл. 10.02.2015, Бюл. № 3.

11. Швед Н. И. Способ прогнозирования исходов острого инфаркта миокарда / Н. И. Швед, О. И. Бакалюк, И. В. Жулкевич. А. с. № 1811376 к патенту от 23.04.1993 г.

nostyka, likuvannia, sposterezhennia: dlia simeinykh likariv, kardiolohiv, terapevtiv [Coronary heart disease in the elderly: diagnosis, treatment, observation: for family doctors, cardiologists, therapists]. Donetsk: Kusum Farm [in Ukrainian].

5. Zannad, F., Dallongeville, J., Macfadyen, R.J., Ruilope, L.M., Wilhelmsen, L., De Backer, G., ..., \& Koenig, W. (2012). Prevention of cardiovascular disease guided by total risk estimations - challenges and opportunities for practical implementation: highlights of a CardioVascular Clinical Trialists (CVCT) Workshop of the ESC Working Group on CardioVascular Pharmacology and Drug Therapy. Eur. J. Prev. Cardiol., 19 (6), 1454-1464.

6. (2017). World Health Statistics. Monitoring Health for the Sustainable Development Goals (SDGs). Geneva: World Health Organization.

7. Kantemirova, R.K., Chernobay, V.G., Arev, A.L., \& Dzahova, S.D. (2010). Farmakoterapiya v geriatricheskoy praktike: ruk. dlya vrachey [Pharmacotherapy in geriatric practice: guidelines. for doctors]. Saint Ptersburg: SpetsLit [in Russian]. 
Огляди літератури, оригінальні дослідження, погляд на проблему, випадок з практики, короткі повідомлення

8. Ushkalova, E.A., Tkacheva, O.N., Runihina, N.K., Chuhareva, N.A., \& Bevz, A.Yu. (2016). Osobennosti farmakoterapii u pozhilykh patsiyentov. Vvedeniye $v$ problemu [Features of pharmacotherapy in elderly patients. Introduction to the problem]. Ratsionalnaya farmakoterapiya v kardiologii-Ration. Pharmacotherapy in Cardiology, 12 (1), 94-100 [in Russian].

9. Komajda, M., Hanon, O., Hochadel, M., Lopez-Sendon, J.L., Follath, F., Ponikowski, P., ..., \& Nieminen, M. (2009). Contemporary management of octogenarians hospitalized for heart failure in Europe: Euro Heart Failure Survey II. Eur. Heart J., 30 (4), 478-486. doi: 10.1093/eurheartj/ehn539.

10. Zharinova, V.Yu., Bodretska, L.A., Korkushko, O.V., Ihrunova, K.M., Butynets, Zh.S., Kokhanovska, L.M., inven- tors; Derzh. ustanova "Instytut herontolohii im. D.F. Chebotarova NAMN Ukrainy", patentee. Sposib likuvannia porushen hemovaskuliarnoho hemostazu u khvorykh na ishemichnu khvorobu sertsia [A method for the treatment of hemostatic haemostasis disorders in patients with ischemic heart disease]. Patent 96488 Ukraina. MPK A61 K 31/175, A 61 P 9/00. zaiavl. 04.08.2014; opubl. 10.02.2015, Biul. No. 3. [in Ukrainian].

11. Shved, N.I., Bakalyuk, O.I., \& Zhulkevich, I.V. (1993). Sposob prognozirovaniya iskhodov ostrogo infarkta miokarda [A method for predicting the outcome of acute myocardial infarction]. A. S. No. 1811376 to the patent of 04/23/1993 [in Russian].

\title{
ОСОБЕННОСТИ ИСПОЛЬЗОВАНИЯ И ЭФФЕКТИВНОСТЬ ОСНОВНЫХ КЛАССОВ ПРЕПАРАТОВ В ЛЕЧЕНИИ ИШЕМИЧЕСКОЙ БОЛЕЗНИ СЕРДЦА У ЛИЦ СТАРШИХ ВОЗРАСТНЫХ ГРУПП
}

\author{
๑В. Ю. Жаринова, Г. П. Войнаровская \\ ГУ «Институт геронтологии имени Д. Ф. Чеботарёва НАМНУ», Киев
}

РЕЗЮМЕ. Значительная смертность и низкое качество жизни больных обусловили необходимость активного поиска комбинаций препаратов, способствующих уменьшению вероятности развития осложнений и улучшению прогноза течения кардиоваскулярных заболеваний.

Цель - особенности использования и эффективность основных классов препаратов для лечения ишемической болезни сердца (ИБС) у лиц старших возрастных групп.

Материал и методы. Были проанализированы 220 историй болезней пациентов в возрасте 60-90 лет с ИБС, находившихся на стационарном и амбулаторном лечении в отделении кардиологии ГУ «Институт геронтологии им. Д. Ф. Чеботарева НАМНУ» в период 1997-2003 и 2015-2017 гг. Определяли частоту применения отдельных классов препаратов на этих этапах наблюдения, частоту назначения различных схем лечения и их влияние на продолжительность жизни лиц пожилого возраста, больных ИБС. На втором этапе работы был также проведен анализ историй болезней 488 пациентов, наблюдавшихся в 1997-2017 гг. в зависимости от наличия инфаркта миокарда (ИМ) в анамнезе. Начальной точкой наблюдения было выбрано дату первой госпитализации в кардиологическое отделение. Все обследованные были впервые госпитализированы в стационар и в дальнейшем наблюдались с основным диагнозом ИБС: стабильная стенокардия напряжения І-ІІІ ФК, СН 0-ІІ Б. Конечными точками наблюдения считали последнюю госпитализацию на момент 2017 г. или наступление смерти пациента. В качестве конечной точки была выбрана смерть пациента, на основе которой изучался показатель продолжительности жизни (который определялся годом/возрастом смерти) или возраст на момент 2017 года.

Результаты. Было показано, что в 1997-2003 гг. чаще всего назначаемыми группами были: $\beta$-блокаторы (57,2 \%), иАПФ (75,2\%), АСК (73,7 \%), статины 60,1 \% и препараты нитроглицеринового ряда (31,0 \%). Сартаны назначались 10,67 \%, БКК - 26,2%. В 2015-2017 гг. препараты из группы ингибиторов ГМГ-КоА-редуктазы, по данным анализа, начали назначаться в 81,1 \% случаев. Значительно меньше применялись препараты нитроглицериново-

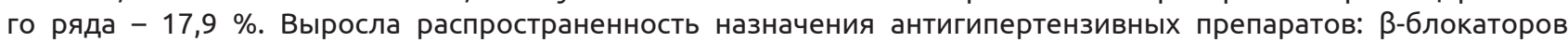
$(80,3 \%)$, блокаторов кальциевых каналов (58,9\%), ингибиторов рецепторов ангиотензина II (35,0\%). Ацетилсалициловая кислота назначалась в 83,7 \% случаев. Анализ терапии больных, перенесших инфаркт миокарда (ИМ), свидетельствует о недостаточном назначении препаратов основных классов: АСК получали 76,2 \%, статины 66,4 \%, бета-блокаторы 73,7, \%, ИАПФ 69,0 \%. В результате применения логистической регрессии нами было построено уравнение, согласно которому может быть спрогнозирована вероятность развития инфаркта в зависимости от того, какими препаратами лечат больного, кроме того, по данным нашей модели можно модифицировать терапию больных, уменьшать вероятность развития ИМ.

Выводы. Полученные результаты свидетельствуют, что наиболее эффективные комбинации лечения лиц с ИБС, влияющие на продолжительность жизни, были у больных, принимавших АСК, статины и бета-блокаторы $(81,4 \pm 3,16)$ года, АСК, статины и ИАПФ - $(80,1 \pm 1,71)$ года.

КЛючЕВЫЕ СЛОВА: ишемическая болезнь сердца; пациенты пожилого возраста; особенности лечения. 
Огляди літератури, оригінальні дослідження, погляд на проблему, випадок з практики, короткі повідомлення

FEATURES OF USE AND EFFECTIVENESS OF THE MAIN CLASSES OF DRUGS FOR THE TREATMENT OF CHD IN ELDERLY PEOPLE

\section{@V. Yu. Zharinova, G. P. Voinarovskaya \\ D. Chebotariov Institute of Gerontology, NAMS of Ukraine}

SUMMARY. The high mortality and poor quality of life of patients led to the need to actively search for combinations of drugs that would reduce the likelihood of complications and improve the prognosis of cardiovascular disease.

The aim - was features of use and effectiveness of the main classes of drugs for the treatment of coronary heart disease in people of older age groups.

Material and Methods. We analyzed 220 case histories of patients aged 60-90 years, with coronary heart disease who were on inpatient and outpatient treatment in the Cardiology Department of D. Chebotariov Istitute of Gerontology in the period from 1997-2003 and 2015-2017. The frequency of application of certain classes of drugs at these stages of observation, the frequency of prescribing various treatment regimens and their effect on the life expectancy of elderly people with coronary heart disease was determined. At the second stage of the work, an analysis of case histories of 488 patients observed from 1997-2017 was also carried out, depending on the presence of Ml in history. According to the initial observation point, the date of the first hospitalization in the cardiology department was selected. All examined patients were hospitalized for the first time in the hospital and were subsequently followed up with the main diagnosis of coronary artery disease: stable angina pectoris I-III FC, CH 0-II B. The final observation points were the last hospitalization at the time of 2017 or the patient's death. The patient's death was chosen as the endpoint, based on which the life expectancy indicator (which was determined by the year/age of death) or age at the time of 2017 was studied.

Results and Discussion. It was shown that in 1997-2003, the most commonly prescribed groups were: $\beta$-blockers (57.2\%), ACE inhibitors (75.2\%), ASA (73.7\%), statins $60.1 \%$ and preparations of the nitroglycerin series (31.0 \%). $10.67 \%$, BKK-26.2 \% were intended for Sartan. In 2015-2017, drugs from the group of HMG-CoA reductase inhibitors, according to the analysis, began to be prescribed in $81.1 \%$ of cases. Nitroglycerin remedies were used much less $17.9 \%$. The prevalence of prescribing antihypertensive drugs has increased: $\beta$-blockers $(80.3 \%)$, calcium channel blockers (58.9\%), angiotensin II receptor inhibitors (35.0\%). Acetylsalicylic acid was intended in $83.7 \%$ of cases. An analysis of the therapy of patients who underwent MI indicates an inadequate prescription of drugs of the main classes of ASA received $76.2 \%$, statins $66.4 \%$, beta blockers $73.7 \%$, ACE inhibitors $69.0 \%$. As a result of the application of logistic regression, we built equations according to which the probability of developing a heart attack can be predicted depending on which drugs are used to treat the patient, and according to our model, the therapy of patients can be modified and the likelihood of developing MI can be reduced.

Conclusions. The results obtained indicate that the most effective treatment combinations for people with coronary heart disease affecting life expectancy were in patients taking ASA, statins and beta blockers $-(81.4 \pm 3.16)$ years, ASA, statins and ACE inhibitors - 80, $(1 \pm 1.71)$ years old.

KEY WORDS: coronary heart disease; elderly patients; features of treatment. 